\title{
PENGARUH KONEKSI POLITIK DAN STRUKTUR KEPEMILIKAN MANAJERIAL TERHADAP NILAI PERUSAHAAN
}

\author{
Ahmad Maulana ${ }^{1}$, Lela Nurlela Wati ${ }^{2}$ \\ ${ }^{1}$ STIE Muhammadiyah Jakarta, ahmadmaulanayusuf120770@gmail.com \\ ${ }^{2}$ STIE Muhammadiyah Jakarta, lela@stiemj.ac.id
}

\begin{abstract}
ABSTRAK
Penelitian ini mengangkat isu Pengaruh koneksi politik dan struktur kepemilikan manajerial terhadap nilai perusahaan berdasarkan fenomena praktik koneksi politik yang terjadi pada perusahaan-perusahaan manufaktur yang berada di Indonesia. Penelitian ini bertujuan untuk menganalisis dan memperoleh bukti empiris pengaruh koneksi politik dan struktur kepemilikan manajerial terhadap nilai perusahaan dimana tujuan jangka panjang dari dibentuknya perusahaan untuk memaksimalkan nilai perusahaan dengan meningkatkan kemakmuran pemilik atau pemegang saham. Sampel penelitian ini menggunakan data sekunder yang berasal dari laporan keuangan perusahaan-perusahaan manufaktur yang terdaftar di Bursa Efek Indonesia pada tahun 2012-2016. Sampel diambil dengan menggunakan purposive sampling dan yang memenuhi kriteria pemilihan sampel. Sampel yang digunakan sebanyak 87 perusahaan. Data diolah dengan software Eviews 9 menggunakan metode General Least Square (GLS). Hasil penelitian menunjukkan bahwa koneksi politik memiliki pengaruh positif signifikan terhadap nilai perusahaan. Sedangkan struktur kepemilikan manajerial tidak berpengaruh signifikan terhadap nilai perusahaan.
\end{abstract}

Kata kunci : Koneksi Politik, Kepemilikan Manajerial, Nilai Perusahaan

\begin{abstract}
This study raises the issue of the influence of political connections and managerial ownership structures on firm value based on the phenomenon of political connection practices that occur in manufacturing companies in Indonesia. This study aims to analyze and obtain empirical evidence of the influence of political connections and managerial ownership structures on the value of the company where the long-term goals of the formation of companies to maximize the value of the company by increasing the prosperity of the owner or shareholders. This research sample uses secondary data derived from the financial statements of manufacturing companies listed on the Indonesia Stock Exchange in 2012-2016. Samples were taken using purposive sampling and that met the sample selection criteria. The sample used was 87 companies. Data is processed with Eviews 9 software using the General Least Square (GLS) method. The results of the study show that political connections have a positive positive effect on company value. While the managerial ownership structure does not have a significant effect on firm value.
\end{abstract}

Keywords: Political Connections, Managerial Ownership, Corporate Values

http://ejournal.stiemj.ac.id/index.php/akuntansi 


\section{PENDAHULUAN}

Indonesia merupakan laboratorium penelitian yang menarik untuk manganalisis pengaruh koneksi politik dan kepemilikan manajerial terhadap nilai perusahaan, karena beberapa alasan. Salah satunya adalah, Indonesia negara dari pasar modal yang baru berkembang dan cenderung tersegmentasi dari pasar modal dunia (Cheung dan Lee, 2003). Nilai perusahaan yang tinggi menunjukkan prestasi kinerja yang baik sehingga menjadi keinginan para pemiliknya. Semakin tinggi nilai perusahaan, semakin besar kemakmuran yang akan diterima oleh pemilik perusahaan, untuk itu semakin tinggi nilai perusahaan, maka akan semakin menarik pihak luar untuk berinvestasi pada suatu peusahaan (Wiagustini, 2013). Naik turunnya nilai perusahaan salah satunya dipengaruhi oleh struktur kepemilikan. Struktur kepemilikan sangat penting dalam menentukan nilai perusahaan. Dua aspek yang perlu dipertimbangkan ialah (1) konsentrasi kepemilikan perusahaan oleh pihak luar (outsider ownership concentration) dan (2) kepemilikan perusahaan oleh manajemen (management ownership). Pemilik perusahaan dari pihak luar berbeda dengan manajer karena kecil kemungkinannya pemilik dari pihak luar terlibat dalam urusan bisnis perusahaan sehari-hari (Sri Rejeki, 2007).

Perusahaan yang terkoneksi politik lebih umum dijumpai pada negara yang memiliki perlindungan hukum yang lemah terhadap investor dan memiliki tingkat korupsi yang tinggi (Faccio, 2006). Bukti empiris mengenai peryataan ini dapat ditemukan pada penelitian Faccio (2006) yang melakukan penelitian cross-country mengenai hubungan politikyang duimiliki perusahaan dan menemukan bahwa perusahaan yang memiliki hubungan politik memang lebih lazim ditemukan pada negara dengan level korupsi yang tinggi dan sistem hukum yang lemah. Indonesia juga merupakan salah satu negara yang memiliki konsentrasi hubungan politik tertinggi dibandingkan dengan negara-negara lain (Faccio, 2006).

Wati (2017) mendukung temuan Facio (2006), dimana koneksi politik di perusahaan konglomerasi di Indonesia dapat meningkatkan kinerja perusahaan baik jangka pendek maupun jangka Panjang. Bukti empiris ini menunjukkan bahwa koneksi politik masih relevan pada perusahaan Indonesia. Terlebih lagi, pada dekade terakhir, semakin banyak berita terkait korupsi birokrasi yang melibatkan pemerintah, perusahaan, dan partai politik yang diangkat keranah umum. Hal ini semakin memperkuat adanya tujuan tersendiri yang bersifat politis saat koneksi politik masuk dalam perusahaan.

Fakta bahwa Indonesia adalah Negara multipartai juga membuat adanya perspektif partai yang harus dikaji. Banyak perusahaan yang memiliki koneksi politik dengan partai politik karena personil partai juga menjabat atau memiliki kepentingan yang cukup besar pada perusahaan terkait. Politisi dan atau figur pemerintah menjaga kepentingan dengan perusahaan tersebut untuk mengendalikan perusahaan demi mencapai tujuan mereka dan tentunya memberi timbal balik kepada para pendukung politik (Bliss dan Gul, 2011).

Fenomena lainnya yang menarik tentang koneksi politik yaitu fenomena kenaikan hargaharga saham pada perusahaan terkoneksi politik pada pemilu 2009 dan 2014. Terdapat indikasi peningkatan nilai pasar konglomerat yang memiliki koneksi politik dengan pemenang pemilihan partai dan Presiden, terutama di perusahaan besar dan perusahaan milik negara (Wati et. al., 2016). Nilai kapitalisasi pasar konglomerat meningkat secara signifikan pasca pemilihan baik pada tahun 2009 atau pada tahun 2014. Peningkatan harga saham perusahaan menunjukkan bahwa para pengusaha dan pemimpin perusahaan di negara-negara berkembang seperti Indonesia dengan tingkat korupsi yang masih tinggi, masih meyakini bahwa koneksi politik menyediakan pelumas untuk mencapai tujuan perusahaan, sehingga mereka melakukan upaya signifikan untuk membina koneksi politik dalam rangka mencapai pertumbuhan perusahaan, mereka menyadari bahwa koneksi politik adalah sumber daya berharga untuk perusahaan (Wati et al., 2016; Li et al., 2012).

Fenomena lainnya dalam banyak kasus di Indonesia dalam proses memaksimalkan nilai perusahaan akan muncul konflik kepentingan antara manajer dan pemegang saham (pemilik perusahaan) yang sering disebut agency problem. Tidak jarang pihak manajemen yaitu manajer perusahaan mempunyai tujuan dan kepentingan lain yang bertentangan dengan tujuan utama 
perusahaan dan sering mengabaikan kepentingan pemegang saham. Perbedaan kepentingan antara manajer dan pemegang saham ini terjadi karena manajer lebih mengutamakan kepentingan pribadi, sebaliknya pemegang saham tidak menyukai kepentingan pribadi dari manajer karena apa yang dilakukan manajer tersebut akan menambah biaya bagi perusahaan sehingga menyebabkan penurunan keuntungan perusahaan dan berpengaruh terhadap nilai perusahaan (Wati, 2016).

Fenomena dalam banyak kasus di Indonesia, kepemilikan saham terbesar pada suatu perusahaan terkosentrasi pada kepemilikan keluarga. Shleifer dan Vishny (1986) berpendapat bahwa konsentrasi kepemilikan memiliki pengaruh terhadap nilai perusahaan dan hubungannya tidak linear. Dijelaskan dalam penelitiannya bahwa kepemilikan yang tersebar menghasilkan masalah free-rider dan membuat manajer semakin sulit dalam melakukan monitoring. Temuan ini menjelaskan bahwa, pada negara dengan kepemilikan tak terkonsentrasi, peningkatan pada konsentrasi kepemilikan akan menyelesaikan masalah free-rider dan monitoring sehingga meningkatkan nilai perusahaan. Namun ketika konsentrasi kepemilikan semakin tinggi, akan memunculkan Agency Problem antara Majority Shareholder dan Minority Shareholder. Jika konsentrasi kepemilikan terlalu tinggi, maka Majority Shareholder dapat melakukan pengambilalihan atau penyalahgunaan asset. Oleh karena itu, penelitian ini mengkaji pengaruh konsentrasi kepemilikan perusahaan di Indonesia, dan hubungannya terhadap nilai perusahaan.

Perusahaan di Indonesia terbagi menjadi dua kategori perusahaan, yaitu perusahaan yang dimiliki oleh negara (BUMN) dan Perusahaan swasta. Rahmani (2004) menyatakan bahwa BUMN yang terdapat di Indonesia kekurangan insentif dan pengawasan. Melihat hasil penelitiannya yang mengambil sampel perusahaan di China, dapat disimpulkan bahwa pada perusahaan dengan ultimate owner-nya, pemerintah dapat dengan bebas mengendalikan strategi manajemen sesuai dengan kepentingannya dan bahkan tak jarang melakukan Asset Tunneling dari perusahaan tersebut untuk kepentingan pemerintah, namun menurut data statistik yang dikeluarkan oleh Bursa Efek Indonesia per Juni 2011, 18 BUMN dari 428 emiten menyumbang 25,9\% dari total kapitalisasi pasar. Hal ini menarik karena perusahaan kepemilikan pemerintah yang disebutkan memiliki kinerja yang cenderung negatif ternyata memiliki kapitalisasi pasar yang besar di dalam Bursa Efek Indonesia.

Bukti empiris mengenai pengaruh Struktur Kepemilikan saham manajerial pada Nilai Perusahaan menunjukkan hasil yang berbeda-beda. Nurlela dan Islahuddin (2008), Wahyudi dan Pawestri (2006), serta Haruman (2008) menemukan bahwa kepemilikan manajerial berpengaruh signifikan terhadap nilai perusahaan. Barclay dan Holderness (1990) menemukan bahwa tingkat kepemilikan institusional berpengaruh positif signifikan terhadap nilai perusahaan. Purba (2004) menemukan bahwa besarnya proporsi saham publik memiliki hubungan (relasi) yang positif dengan kinerja perusahaan yang berimbas pada nilai perusahaan.

Hasil yang berbeda didapati oleh Sujoko dan Soebiantoro (2007). menemukan bukti bahwa kepemilikan manajerial tidak berpengaruh terhadap nilai perusahaan. Begitu pula Sofyaningsih dan Hardiningsih (2011) yang tidak dapat membukti kan pengaruh kepemilikan institusional pada nilai perusahaan, serta Soepriyanto (2004) dalam Sofyaningsih dan Hardiningsih (2011) menemukan bukti bahwa Kepemilikan Publik tidak berpengaruh terhadap nilai perusahaan.

\section{KAJIAN LITERATUR}

\section{Teori Agensi}

Teori keagenan menjelaskan mengenai hubungan antara pemegang saham sebagai principal dan manajemen sebagai agen. Dalam mengelola suatu perusahaan pemegang saham mengontrak agen (manajemen) untuk bekerja mengelola perusahaan demi kepentingan pemegang saham. Pihak manajemen harus mempertanggungjawabkan pekerjaannya kepada struktur kepemilikan. Menurut penelitian Jensen dan Meckling (1976) hubungan keagenan merupakan suatu hubungan dimana pemilik perusahaan (principle) mempercayakan pengelolaan perusahaan 
oleh orang lain yaitu manajer (agent) sesuai dengan kepentingan pemilik (principle) dengan mendelegasikan beberapa wewenang pengambilan keputusan kepada manajer (agent).

Manajer dalam menjalankan perusahaan mempunyai kewajiban untuk mengelola perusahaan sebagaimana diamanahkan oleh pemilik (principle) yaitu meningkatkan kemakmuran prinsipal melalui peningkatan nilai perusahaan, sebagai imbalannya manajer (agent) akan mendapatkan gaji, bonus atau kompensasi lainnya. Principal mempekerjakan agent untuk melakukan tugas untuk kepentingan principal, termasuk pendelegasian otorisasi pengambilan keputusan dari principal. Pemilik modal menghendaki bertambahnya kekayaan dan kemakmuran kepada para pemilik modal, sedangkan manajer juga menginginkan bertambahnya kesejahteraan bagi para manajer. Hal ini menyebabkan timbul konflik antara manajemen dengan pemilik karena masing-masing akan memenuhi kepentingannya sendiri (opportunistic behavioral). Pemilik akan mengeluarkan biaya monitoring untuk mengawasi kinerja manajemen. Dasar dari teori agensi dalam penelitian ini adalah adanya perbedaan kepentingan antara agen dan principal untuk memaksimumkan kesejahteraannya masing-masing.

\section{Nilai Perusahaan}

Nilai perusahaan mencerminkan tingkat kesejahteraan perusahaan tersebut. Semakin tinggi nilainya maka akan semakin tinggi juga pandangan masyarakat terhadap tingkat kesejahteraan perusahaan tersebut. Untuk mengukur nilai perusahaan digunakan metode yang dikenal dengan nama Tobin;s Q. Tobin's Q sendiri adalah suatu instrument yang dikembangkan oleh professor James Tobin yang menunjukan estimasi pasar keuangan saat ini atas tiap pengembalian dari investasi. Tobin's Q dihitung dengan menggunakan persamaan matematika sebagai berikut:

$$
\text { Tobin' }^{\prime} Q=\frac{\{(\text { CPx Jumlah Saham })+T L+I)\}-C A}{\text { TA }}
$$

Dimana:

$$
\begin{array}{ll}
\mathrm{CP} & =\text { Closing Price } \\
\mathrm{TL} & =\text { Total Liabilities } \\
\mathrm{I} & =\text { Inventory } \\
\mathrm{CA} & =\text { Current Assets } \\
\mathrm{TA} & =\text { Total Assets }
\end{array}
$$

\section{Koneksi Politik}

Variabel koneksi politik dalam penelitian ini yaitu perusahaan terkoneksi politik apabila sedikitnya salah satu anggota dari Dewan Komisaris yang menjabat ataupun sudah tidak menjabat sebagai pejabat pemerintahan Negara meliputi lembaga-lembaga eksekutif (Kementerian Negara, Departemen, Lembaga Pemerintah Non Departemen dan organisasi pemerintah pusat lainnya), lembaga legislatif (badan-badan perwakilan rakyat), lembaga yudikatif (badan-badan peradilan) dan lembaga-lembaga lainnya yang diperlukan dalam tatanan Negara. Pada penelitian yang dilakukan Kozlowski, Jackowicz, Mielcarz (2014). Hubungan politik perusahaan, perusahaan dikatakan memiliki koneksi politik jika paling tidak salah satu dari pimpinan perusahaan (dewan komisaris atau dewan direksi), pemegang saham mayoritas atau kerabat mereka pernah atau sedang menjabat sebagai pejabat tinggi negara, anggota parlemen atau dekat dengan politisi atau partai politik, digunakan variable dhummy untuk menggambarkan koneksi politik, yaitu dengan memberi angka 1 bagi perusahaan yang terkoneksi politik dan angka 0 bagi perusahaan yang tidak terkoneksi politik. Perusahaan memiliki hubungan politik yaitu 1). Dewan direksi dan/atau dewan komisaris rangkap jabatan sebagai pejabat pemerintah. 2). Dewan direksi dan /atau komisaris merupakan mantan pejabat pemerintah. 3). Pemilik perusahaan atau pemegang saham merupakan politisi pejabat pemerintah atau mantan pejabat pemerintah. 4). Pemilik perusahaan atau pemegang saham memiliki hubungan kedekatan dengan politisi/partai politik, pejabat pemerintah, atau mantan pejabat pemerintah. Mengacu pada penelitian Faccio (2006). 


\section{Struktur Kepemilikan Manajerial}

Kepemilikan manajerial merupakan porsi outstanding share yang dimiliki oleh investor terhadap jumlah seluruh modal saham yang beredar. pemilik memiliki kewenangan yang besar untuk memilih siapa-siapa yang akan duduk dalam manajemen yang selanjutnya akan menentukan arah kebijakan bank tersebut ke depan. Dalam penelitian ini kepemilikan institusional diukur dengan menggunakan indikator persentase jumlah saham yang dimiliki institusi dari seluruh modal saham yang beredar di pasar saham:

Kepemilikan Manajerial $($ MANAJ $)=\frac{\text { Jumlah Saham manajerial }}{\text { Jumlah Saham beredar di pasar }} \times 100$

\section{Variabel Kontrol}

Usia Perusahaan

Variabel umur perusahaan atau firm age dapat dinilai yaitu dengan melihat tanggal pendiriannya maupun dari tanggal terdaftarnya di BEI atau saat perusahaan melakukan innital public offering (IPO). Umur perusahaan dalam penelitian ini menggunakan umur perusahaan dari tanggal perusahaan terdaftar di bursa efek. Hal ini dikarenakan, pada saat suatu perusahaan sudah terdaftar dibursa efek Indonesia dan go public. Maka perusahaan harus mempublikasikan pelaporan tahunan mereka kepada masyarakat dan pemakaian laporan tahunan agar informasi yang terkandung didalamnya dapat segera digunakan oleh pihak-pihak yang membutuhkan tersebut.

Age $=($ Tahun penelitian - First Issued di BEI $)$

\section{Pengembangan Hipotesis}

Penelitian yang mendukung adanya hubungan antara koneksi politik dengan nilai perusahaan adalah Zhang, et.al., (2010) Keuntungan lain yang di dapat oleh perusahaan yang berkoneksi politik adalah akses yang lebih mudah untuk pembiayaan hutang, pajak yang lebih rendah, dan kekuatan pasar yang lebih kuat. Zhang et, al. memberikan contoh dari hasil laporan penelitiannya bahwa bankir sering dipaksa untuk memberikan pinjaman bagi proyek-proyek yang dilakukan oleh perusahaan yang berkoneksi politik meskipun proyek tersebut diperkirakan tidak menguntungkan. Hubungan politik perusahaan pada dasarnya memberikan dampak yang signifikan bagi aktivitas ekonomi perusahaan. Fisman (2001) mengemukakan bahwa hubungan politik dapat menjadi sumber daya perusahaan yang berharga bila diasosiasikan dengan nilai reputasi dan fungi proteksi yang dibangun karena adanya hubungan politik tersebut. Adapun berbagai motivasi yang ingin dicapai oleh perusahaan dengan dibangunnya hubungan politik, diantaranya adalah memperkuat posisi perusahaan diantara para kompetitornya (Bushman \& Piotroski, 2006), menghindari peraturan yang ketat yaitu dengan cara menurunkan banyak kontrak (Fisman, 2001.

Sedangkan hasil penelitian Fan et al. (2004) melaporkan hasil yang berbeda pada hasil penelitiannya bahwa perusahaan yang memiliki CEO berkoneksi politik memiliki kinerja yang lebih rendah sekitar $37 \%$ tentunya berdampak pada nilai perusahaan. Perusahaan yang memiliki hubungan politik sering diasosiasikan dengan kualitas pelaporan akuntansi yang rendah (Chaney et al, 2011). Perusahaan yang memiliki hubungan politik juga cenderung memiliki kinerja yang lebih buruk dibandingankan dengan perusahaan lain (Faccio, 2006). Hal ini terjadi karena manager pada perusahaan yang memiliki hubungan politik tidak mempunyai insentif untuk meningkatkan transparansi, dan hanya peduli pada perolehan keuntungan pribadi yang terkadang mengorbankan stakeholder lainnya (Faccio, 2006).

Peningkatan harga saham perusahaan menunjukkan bahwa para pengusaha dan pemimpin perusahaan di negara-negara berkembang seperti Indonesia dengan tingkat korupsi yang masih tinggi, masih meyakini bahwa koneksi politik menyediakan pelumas untuk mencapai tujuan perusahaan, sehingga mereka melakukan upaya signifikan untuk membina koneksi politik dalam 
rangka mencapai pertumbuhan perusahaan, mereka menyadari bahwa koneksi politik adalah sumber daya berharga untuk perusahaan (Wati et al., 2016; Li et al., 2012).

Wati (2017) memberikan bukti empiris bahwa koneksi politik memberikan dampak positif terhadap nilai perusahaan.

Berdasarkan penjelasan tersebut diatas maka hipotesisnya adalah sebagi berikut :

\section{H1 : Koneksi politik berpengaruh positif terhadap nilai perusahaan}

Bukti empiris mengenai pengaruh struktur kepemilikan manajerial pada nilai perusahaan menunjukkan hasil yang berbeda-beda. Nurlela dan Islahuddin (2008), Wahyudi dan Pawestri (2006), serta Haruman (2008) menemukan bahwa kepemilikan manajerial berpengaruh signifikan terhadap nilai perusahaan. Barclay dan Holderness (1990) menemukan bahwa tingkat kepemilikan manajerial berpengaruh positif signifikan terhadap nilai perusahaan. Purba (2004) menemukan bahwa besarnya proporsi saham publik memiliki hubungan (relasi) yang positif dengan kinerja perusahaan yang berimbas pada nilai perusahaan.

Berdasarkan penjelasan tersebut diatas maka hipotesisnya adalah sebagi berikut :

\section{H2 : Pemegang saham manajerial berpengaruh positif terhadap nilai perusahaan}

\section{KERANGKA PIKIR}

Penelitian ini menguji pengaruh dua variabel independen, yaitu koneksi politik dan pemegang saham pengendali terhadap nilai perusahaan, serta menguji dengan menggunakan, Age, sebagai variabel kontrol. Berdasarkan hubungan tersebut maka kerangka penelitian yang digunakan dalam penelitian ini adalah sebagi berikut :

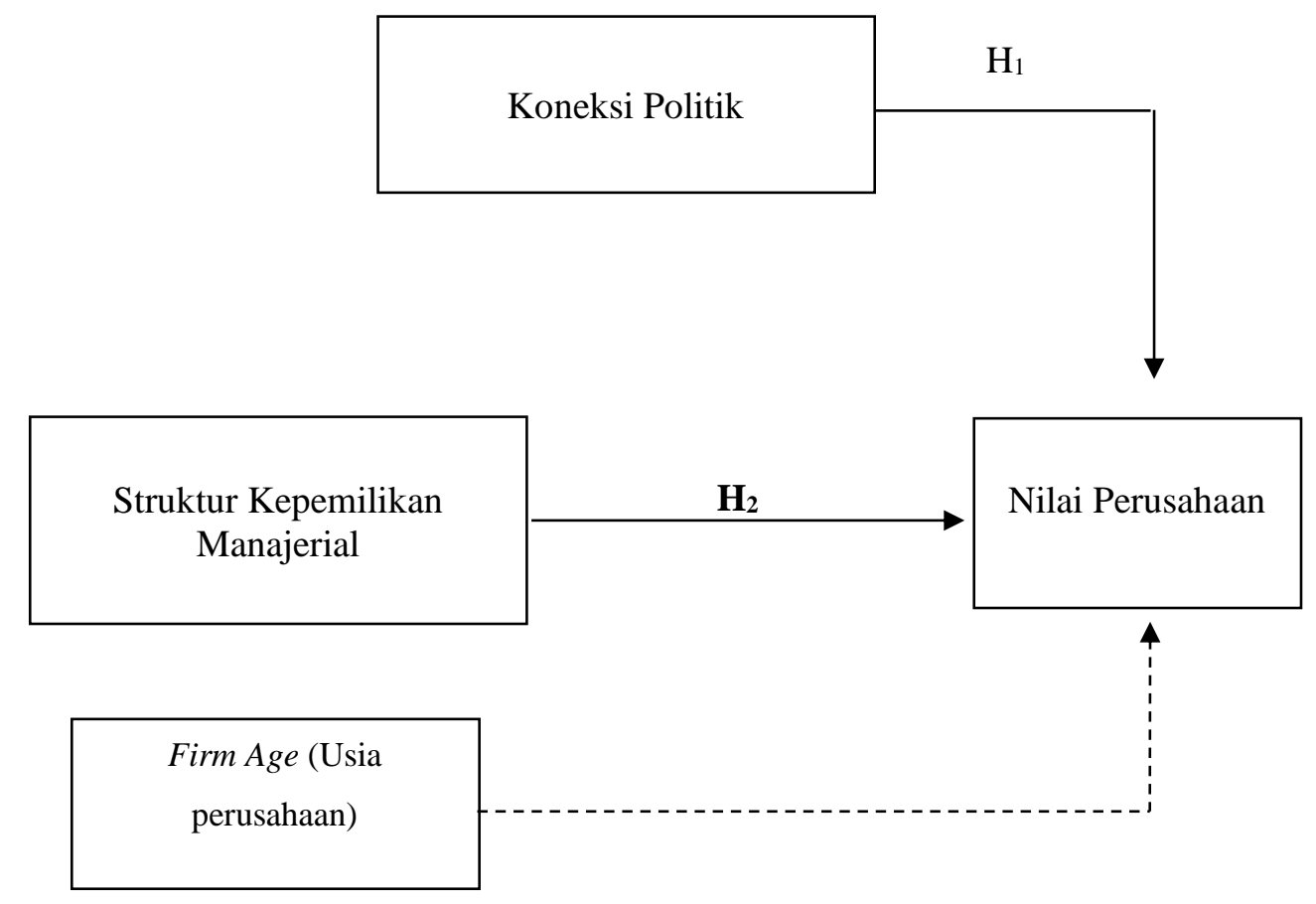

Gambar 1. Kerangka Pikir

\section{METODE PENELITIAN}

Penelitian ini menggunakan sampel perusahaan manufaktur yang annual report dari tahun 2012 sampai dengan 2016. Alasan memilih perusahaan manufaktur sebagai objek penelitian karena perusahaan bergerak di sektor riil. Selain itu sektor manufaktur merupakan emiten terbesar perusahaan dibandingkan sektor lainnya. Jumlah perusahaan manufaktur yang listed di BEI tahun 
2016 sebanyak 135 perusahaan, namun setelah diseleksi berdasarkan kriteria yang ditetapkan maka diperoleh sampel akhir sebanyak 87 perusahaan.

Tabel 1

Data Kriteria Sampel Perusahaan

\begin{tabular}{|l|c|}
\hline Kriteria & Jumlah \\
\hline Perusahaan Manufaktur yang terdaftar di BEI & 135 \\
\hline Perusahaan dengan annual report tidak lengkap & 40 \\
\hline Perusahaan yang sahamnya tidak aktif selama periode penelitian & 7 \\
\hline Perusahan yang delisting & 3 \\
\hline Jumlah Sampel & 87 \\
\hline
\end{tabular}

Sumber :Data diolah 2018

Dalam penelitian ini dapat dibentuk persamaan :

Model Penelitian :

Tobins' $Q=\alpha+\beta 1 \mathrm{KP}_{\mathrm{it}}+\beta 2 \mathrm{MANAJ}+\beta 3$ Firm Age $_{\mathrm{it}}+\mathrm{e}$

Dimana :

$\begin{array}{ll}\mathrm{I} & =\text { perusahaan sampel } \\ \mathrm{T} & =\text { tahun penelitian } \\ \mathrm{B} & =\text { Konstanta } \\ \mathrm{A} & =\text { Koefisien regresi } \\ \mathrm{E} & =\text { Standar eror } \\ \text { KP } & =\text { Koneksi Politik } \\ \text { MANAJ } & =\text { Kepemilikan Manajerial } \\ \text { Firm Age } & =\text { Tahun penelitian - First Issued di BEI }) \\ \text { Tobin's Q } & =\text { Pengukuran Nilai Perusahaan }\end{array}$

\section{ANALISIS DATA DAN PEMBAHASAN}

Tabel 2

Daftar Hasil Penelitian

\begin{tabular}{|l|c|c|c|c|}
\hline \multirow{2}{*}{ Variabel } & \multicolumn{4}{|c|}{$\mathrm{N}=435$} \\
\cline { 2 - 5 } & Min & Max & Mean & St. Dev \\
\hline Tobins Q & 0.1881 & 18.6404 & 1.919425977 & 2.545496165 \\
\hline Koneksi Politik & 0 & 1 & 0.418390805 & 0.493862967 \\
\hline KPM & 0 & 0.7 & 0.031602997 & 0.093089041 \\
\hline AGE & 2 & 39 & 19.66666667 & 7.401685365 \\
\hline
\end{tabular}

Sumber: Data diolah, 2018

Berdasarkan data pada tabel 2 di atas, terlihat bahwa nilai minimum Tobin's Q sebesar 0,1881 dan maksimum sebesar 18.6404. Sementara nilai standard deviasi Tobin's Q sebesar sebesar 2,5454, dengan nilai rata-rata Tobin's Q yang dimiliki perusahaan manufaktur periode 2012-2016 adalah 1,9194. Nilai terendah dimiliki oleh PT. Delta Djakarta Tbk pada tahun 2016, dan yang tertinggi PT. Unilever IndonesiaTbk pada tahun 2015. Tobin's Q yang memiliki nilai lebih dari satu mempunyai makna bahwa perusahaan mampu menghasilkan laba dengan tingkat return yang sesuai dengan harga perolehan asetnya-asetnya.

Nilai koneksi politik minimum sebesar 0 dan maksimum sebesar 1 . Sementara nilai ratarata Koneksi politik sebesar 0.4183 dan nilai standard deviasi sebesar 0.4938. Nilai 1 Koneksi 
Politik dimiliki oleh Polychem Indonesia Tbk, PT. Tiga Pilar Sejahtera Food Tbk, PT. Alumindo Light Tbk, PT. Arwana Citramulia Tbk, PT. Astra Internasional Tbk, PT. Astra Otoparts Tbk, PT. Charoen Phokphandk Indonesia Tbk, PT. Citra Tubindo Tbk, PT. Delta Djakarta Tbk, PT. Daria Varia LaboratoriaTbk, PT. Ekadharma Internasional Tbk, PT. Eratex Djaja Tbk, PT. Fajar Surya Wisesa Tbk, PT. Gajah Tunggal Tbk, PT. Gajah Tunggal Tbk, PT. HM Sampoerna Tbk, PT. Indofarma (Persero)Tbk, PT. Indorama Synthetics Tbk, PT. Indospring Tbk, PT. Toba Pulp Lestari Tbk, PT. Jembo Cable CompanyTbk, PT. Jakarta Kyoel Steel Work Tbk, PT. Kimia Farma (Persero)Tbk, PT. KMI Wire and Cable Tbk, PT. Krakatau Steel Tbk, PT. Multi Bintang Indonesia Tbk, PT. Mulia Industrindo Tbk, PT. Pelat Timah NusantaraTbk, PT. Pelangi Indah CanindoTbk, PT. Bentoel Internasional InvestamaTbk, PT. Holcim Indonesia Tbk, PT. Pabrik Kertas Tjiwi Kimia Tbk, PT. Surya Toto Indonesia Tbk, PT. Unggul Indah Cahaya Tbk, PT. Unilever Indonesia Tbk.

Nilai Kepemilikan manajerial (KPM) minimum sebesar 0 (dimana kepemilikan saham manajerial tidak ada) dan maksimum sebesar 0,70 (dimana kepemilikan saham manajerial sebesar 0,70) yaitu terendah pada tahun 2012 dan tertinggi tahun 2016 Nilai kepemilikan manajerial minimum sebesar 0 dan maksimum sebesar 0,70 . Sementara nilai rata-rata kepemilikan manajerial sebesar 0.0316 dan nilai standar deviasi sebesar 0.0930. Nilai kepemilikan manajerial tertinggi dimiliki oleh PT. Sat Nusapersada Tbk.

Nilai firmage minimum sebesar 2 tahun dan maksimum usia perusahaan terlama yaitu 39 tahun. Sementara nilai rata-rata firm age sebesar 19.6666 dan nilai standard deviasi sebesar 7.4016. Nilai firm age tertinggi dimiliki oleh PT. Holcim Indonesia Tbk dan yang terendah dimiliki oleh PT. Indofood CBP Sukses Makmur Tbk, PT. Indopoly Swakarsa Industry Tbk, PT. Krakatau Steel (Persero) Tbk, dan PT. Nippon Indosari Corpindo Tbk pada tahun 2012.

Tabel 3

Hasil Pengujian Model Penelitian

\begin{tabular}{llllll} 
Variabel & Prediksi & Main Model & Hipotesis & $\begin{array}{l}\text { Robust } \\
\text { Model }\end{array}$ & Hipotesis \\
\hline $\begin{array}{lllll}\text { Constant } \\
\text { POL }\end{array}$ & BPositif & $\begin{array}{l}0,677582 \\
0,939250 \\
(12,31346)\end{array}$ & Didukung & $\begin{array}{l}1.144309 \\
1,276644 \\
(2549046)\end{array}$ & Didukung \\
& & & & \\
MANAJ & BPositif & $-0,273058$ & Tidak & 0,580256 & Tidak Didukung \\
& & $(-0,979190)$ & Didukung & $(-1,379736)$ & \\
Age & & 0,022207 & & & \\
& $(5,489454)$ & & & \\
$R^{2}$ & 0,365426 & & 0,608678 & \\
Adjusted $R^{2}$ & 0,3661009 & & 0,606866 & \\
F.stat & 82,73180 & & 335,9752 &
\end{tabular}

Sumber: Data Diolah, 2018

Koefisien regresi yang diperoleh dari pengaruh variabel Koneksi Politik terhadap nilai perusahaan adalah sebesar 0,939250 dengan nilai tstatistik 12,31346>1,96 pada taraf signifikan 
$\alpha=0,05(5 \%)$ dengan nilai signifikan $0,0000<0,05$ yang menyatakan bahwa terdapat pengaruh positif dan signifikan antara koneksi politik dengan nilai perusahaan. Nilai 0,939250 pada koefisien regresi menunjukkan bahwa setiap koneksi naik 1 maka nilai perusahaan akan naik sebesar 0,939250 . begitu pula sebaliknya jika koneksi politik turun 1 maka nilai perusahaan akan turun sebesar 0,939250. Hasil penelitian ini mendukung hipotesis pertama dimana terdapat pengaruh positif dan signifikan koneksi politik terhadap nilai perusahaan, dengan demikian hipotesis pertama (H1) diterima. Hasil ini konsisten dengan Robust Model. Pada pembuktian hipotesis pertama hasil penelitian menunjukkan bahwa terbukti ada pengaruh positif signifikan antara koneksi politik terhadap nilai perusahaan, hal ini konsisten dengan yang dikemukakan oleh Fan, Wong, dan Zhang (2007) bahwa birokrat atau politisi menggunakan sumber daya dari perusahaan milik negara pimpinanya yang tercatat di bursa untuk memenuhi tujuan yang tidak konsisten dengan tujuan memaksimalkan nilai perusahaan.

Koefisien regresi yang diperoleh dari Struktur Kepemilikan Manajerial terhadap nilai perusahaan adalah sebesar $-0,273058$ dengan nilai tstatistik $-0,979190<1,96$ pada tarif signifikan $\alpha=0,05(5 \%)$ dengan nilai signifikan $0,323280>0,05$. yang menyatakan bahwa terdapat pengaruh negatif dan tidak signifikan struktur kepemilikan manajerial terhadap nilai perusahaan. Nilai $-0,273058$ pada koefisien regresi artinya setiap interaksi kepemilikan manajerial naik maka nilai perusahaan akan turun sebesar $-0,273058$, dan begitu juga sebaliknya. Dengan demikian hasil empiris ini tidak mendukung hipotesis penelitian yang kedua, dimana tidak terdapat pengaruh positif Kepemilikan Manajerial terhadap nilai perusahaan. Dari hasil tersebut dapat disimpulkan bahwa hipotesis ketiga (H2) ditolak. Hal ini mendukung penelitian Pertiwi dan Madi (2012), dan Herawati (2006) yang menunjukkan bahwa kepemilikan manajerial tidak selalu berdampak positif terhadap nilai perusahaan. Perbedaan kepentingan antara manajer dan pemegang saham akan menimbulkan agency conflict, hal tersebut terjadi karena manajer mengutamakan kepentingan pribadi, sebaliknya pemegang saham tidak menyukai kepentingan pribadi dari manajer karena apa yang dilakukan manajer tersebut akan menambah biaya bagi perusahaan sehingga menyebabkan penurunan keuntungan perusahaan dan berpengaruh terhadap harga saham sehingga menurunkan nilai perusahaan (Jensen dan Meckling, 1976).

Dari hasil tabel 3 diatas terdapat kontrol variabel yaitu age, yang berpengaruh positif signifikan terhadap nilai perusahaan. Hasil ini menunjukkan bahwa semakin usia perusahaan meningkat maka nilai perusahaan juga akan meningkat. Begitu pula dengan size perusahaan, semakin besar size perusahaan semakin besar pula nilai perusahaan. Dilihat dari robust test model, dimana variabel kontrol yaitu age dihilangkan, menunjukkan hasil pengujian yang konsisten dengan model penelitian utama, dimana koneksi politik berpengaruh positif terhadap nilai perusahaan. Begitu juga dengan hasil konsisten yang didapat antara kepemilikan Manajerial dengan Nilai perusahaan. Hal ini menunjukkan bahwa hasil penelitian ini dikatakan robust atau kokoh. Model penelitian dalam tabel 3 di atas, dapat dijelaskan sebagai berikut: Tobins' $Q=0,677582+0,939250 K P_{i t}+-0,273058 M^{2} A N A J_{i t}+0,022207$ Age $_{i t}$

Nilai konstanta sebesar 0,677582 dapat diartikan jika tidak ada koneksi politik dan kepemilikan manajerial maka nilai perusahaan adalah sebesar 0,677582. Pada model regresi penelitian, interaksi Koneksi Politik mempunyai nilai koefisien regresi yang paling besar jika dibandingkan dengan koefisien regresi lainnya dengan nilai koefisien regresi sebesar 0,939250. Artinya Koneksi politik mempunyai pengaruh yang paling besar terhadap nilai perusahaan.

Nilai adjusted $R$ square (determinasi) sebesar 0,3661009, artinya nilai perusahaan dipengaruhi oleh Koneksi Politik sebesar 36,61\% dan sisanya sebesar $63.39 \%$ dipengaruhi oleh faktor lain diluar penelitian. Variabel yang memberikan pengaruh terkecil terhadap nilai perusahaan adalah MANAJ yang dengan nilai koefisien regresi -0,273058. Hal ini dikarenakan persentase kepemilikan manajerial yang relatif kecil di perusahaan.

\section{Pembahasan}


Pada pembuktian hipotesis pertama hasil penelitian menunjukkan bahwa terbukti ada pengaruh positif signifikan antara koneksi politik terhadap nilai perusahaan, hal ini konsisten dengan yang dikemukakan oleh Fan, Wong, dan Zhang (2007) bahwa birokrat atau politisi menggunakan sumber daya dari perusahaan milik negara pimpinanya yang tercatat di bursa untuk memenuhi tujuan yang tidak konsisten dengan tujuan memaksimalkan nilai perusahaan. Hillman (2005) lebih lanjut mengatakan bahwa sumber utama dari saling ketergantungan (inter dependency) bagi suatu bisnis adalah pemerintah. Penelitian yang berhubungan dengan Teori Recource Dependence mununjukkan bahwa board capital (legitimasi, anjuran dan saran, hubungan/koneksi dengan organisasi lain, dan lain-lain) memiliki hubungan dengan kinerja perusahaan (Boyd, 1990; Dalron, Daily, Johnson, dan Ellstrand, 1999).

Berdasarkan penelitian sebelumnya, telah dibuktikan bahwa terdapat hubungan positif antara koneksi politik dan nilai perusahaan pada negara dengan sistem hukum yang lemah maupun yang kuat (Faccio, 2006; Faccio dan Parsley, 2007; Fisman, 2001; Goldman etal., 2007; Wati, 2017). Terdapat beberapa alasan yang mungkin dapat menjelaskan mengapa perusahaan dengan koneksi politik mungkin untuk memiliki kinerja yang lebih baik daripada perusahaan lainnya (Niessen dan Ruenzi, 2010); pertama delagasi (politisi) hanya memilih perusahaan dengan kinerja yang paling baik sebagai tempatnya bekerja untuk melindungi reputasinya; kedua, politisi biasanya memiliki sudut pandang orang luar perusahaan yang dapat memberi pandangan independen terhadap perusahaan yang dapat memberi dampak positif terhadap kinerja; ketiga, koneksi politk dapat memberi competitive advantage bagi perusahaan seperti akses yang lebih mudah untuk pendanaan yang berasal dari pinjaman, tarif pajak yang lebih rendah, kontrak dengan perusahaan, atau mengurangi persyaratan regulasi.

Koneksi politik memiliki peran yang penting dalam perekonomian dimana hukum dan penegakkan hukum lemah, kualitas dari institusi independen untuk mengawasi pemerintah buruk, dan tingkat korupsi tinggi (Polsiri dan Jiraporn, 2012). Dikemukakan oleh Bartels dan Brady (2003) dalam Polsiri dan Jirapron (2012) bahwa dalam lingkungan yang telah dipaparkan sebelumnya, kelompok bisnis yang berpengaruh kemungkinan akan mencoba untuk mendapatkan pengaruh politik dalam rangka untuk mengekploitasi sumber daya ekonomi demi kepentingan mereka sendiri dengan membebankan ke masyarakat. Sebagai alternatif, perusahaan mungkin akan mencoba mempengaruhi politisi melalui penyuapan (Shleifer dan Vishny, 1994 dalam Polsiri dan Jiraporn 2012).

Pada pengujian hipotesis kedua, kepemilikan manajerial tidak berpengaruh signifikan terhadap nilai perusahaan. Hasil penelitian ini mendukung penelitian Pertiwi dan Madi (2012), dan Herawati (2006) yang menunjukkan bahwa kepemilikan manajerial tidak selalu berdampak positif terhadap nilai perusahaan. Perbedaan kepentingan antara manajer dan pemegang saham akan menimbulkan agency conflict, hal tersebut terjadi karena manajer mengutamakan kepentingan pribadi, sebaliknya pemegang saham tidak menyukai kepentingan pribadi dari manajer karena apa yang dilakukan manajer tersebut akan menambah biaya bagi perusahaan sehingga menyebabkan penurunan keuntungan perusahaan dan berpengaruh terhadap harga saham sehingga menurunkan nilai perusahaan (Jensen dan Meckling, 1976).

Berdasarkan penelitian yang dilakukan oleh Wati (2016) ditemukan bahwa pada tahun 2014 struktur kepemilikan di Indonesia dikendalikan oleh keluarga sebesar 68,10\%. Hal ini menunjukkan rendahnya struktur kepemilikan manajerial karena sebagian besar masih didominasi oleh keluarga. Adanya konsentrasi kepemilikan keluarga mengakibatkan sulitnya manajer dalam menentukan kebijakan karena hak voting dan power yang mayorias dimiliki oleh pemilik dalam penentuan kebijakan sehingga kebijakan yang diambil terkadang bertentangan dengan kepentingan manajer hal ini didukung oleh rata-rata kepemilikan manajerial yang hanya sebesar 0.0316 Dengan rata-rata kepemilikan sebesar itu tentu akan sulit bagi manajer untuk membuat kebijakan atau menentukan tujuan perusahaan jika dihadapkan pada pemilik saham mayoritas.

\section{PENUTUP}


Penelitian ini menyimpulkan bahwa koneksi politik berpengaruh positif terhadap nilai perusahaan. Semakin tinggi koneksi politik maka semakin tinggi nilai perusahaan. Kepemilikan manajerial terhadap nilai perusahaan tidak berpengaruh signifikan. Hal ini dikarenakan adanya agency conflict dan juga proporsi saham yang dimiliki oleh dewan direksi maupun komisaris sangat kecil dengan rata-rata hanya 0,03160. Dengan begitu akan sulit bagi manajerial untuk memegang kontrol dan kendali terhadap keputusan strategis perusahaan. Selain itu mayoritas perusahaan di Indonesia yang masih didominasi oleh kepemilikan keluarga, sehingga hal tersebut akan mendorong praktek korupsi, kolusi, dan nepotisme yang pada akhirnya akan menjatuhkan nilai perusahaan.

Adapun implikasi dari hasil penelitian ini adalah diharapkan dapat menjadi acuan bagi investor dalam menginvestasikan modalnya pada suatu perusahaan. Investor sebaiknya memperhatikan variabel koneksi politik, karena besarnya pengaruh koneksi politik dapat menunjukkan pengaruh terhaadap besarnya nilai perusahaan Perusahaan diharapkan terus meningkatkan nilai perusahaan, namun dengan cara yang positif dan fair yaitu dengan cara meningkatkan prestasi perusahaan, bukan dengan cara peningkatan koneksi politik ataupun lobbylobby kepentingan politik walaupun berdampak positif terhadap nilai perusahaan. Kepemilikan manajerial yang dilakukan oleh perusahaan diharapkan dilakukan secara berkelanjutan karena dengan rasio kepemilikan saat ini yang begitu kecil tidak mempengaruhi terhadap nilai perusahaan.

Pemerintah sudah seharusnya Pemerintah dapat mengendalikan perusahaan-perusahaan dengan mengeluarkan regulasi atau kebijakan-kebijakan pembatasan sampai dengan pelarangan perusahaan melakukan praktik lobbying politik dan memberikan apresiasi bagi perusahaan yang mengedepankan persaingan yang sehat serta fair. Masih terbatasnya literatur yang membahas tentang koneksi politik dan struktuk kepemilikan maka diharapkan semakin banyak penelitian yang di fokuskan kepada hal-hal tersebut. Diharapkan tersedianya "bank data" dikemudian hari untuk dapat menunjang dan membantu peneitian penelitian selajutnya, dikarenakan cukup sulit untuk memperoleh data dalam penelitian keuangan. Meningkatkan sumber referensi yang ada terutama dalam hal yang berkaitan dengan data keuangan dan data profil lengkap struktur perusahaan.

\section{REFERENSI}

Barclay, Michael and Clifford Holderness, 1990, Negotiated block trades and corporate control, Working paper (University of Rochester, Rochester, NY).

Bliss, M. A., Gul, F. A., \& Majid, A. (2011). Do Political Connections Affect The Role of Independent Audit Committees and CEO Duality? Some Evidence from Malaysian Audit Pricing.Journal of Contemporary Accounting \& Economics, 7(2), 82-98.

Bushman, R. M., \& Piotroski, J. D. (2006). Financial reporting incentives for conservative accounting: The influence of legal and political institutions. Journal of Accounting and Economics, 42(1-2), 107-148.

Cheung, K., Lee, F., \& Ip, R. (2003). Enhancing e-government in developing countries: managing knowledge through virtual communities. The Electronic Journal of Information Systems in Developing Countries, 14(1), 1-20.

Chaney, P.K., Faccio, M., Parsley, D.C., 2008. The quality of accounting information in politically connected firms. Unpublished working paper. Vanderbilt University.

Chaney, P.K., Faccio, M., and Parsley, D. (2010). The Quality of Accounting Information In Politically Connected Firms. AFA 2010 Atlanta Meetings Paper. Available at http://papers. ssrn.com. Diakses 10 May 2015.

Fan, J.P.H., Wong, T.J., Zhang, T., 2007. Politically connected CEOs, corporate governance and Post-IPO performance of China's newly partially privatized firms. Journal of Financial Economics 84, 330-357.

Fisman, R. (2001). Estimating the value of political connections. American economic review, 91(4), 1095-1102. 
Haruman, T. (2008). Pengaruh Struktur Kepemilikan Terhadap Keputusan Keuangan dan Nilai Perusahaan Survey pada Perusahaan Manufaktur di PT. Bursa Efek Indonesia.

Herawati, Vinola. (2008). Peran Praktek Corporate Governance sebagai Moderating Variabel dari Pengukuran Earnings Management terhadap Nilai Perusahaan. SNA XI, Pontianak

Islahudin, R. N. (2008). Pengaruh Corporate Social Responsibility Terhadap Nilai Perusahaan Dengan Prosentase Kepemilikan Manajemen Sebagai Variabel Moderating: Studi Empiris Pada Perusahann Yang Terdaftar di Bursa Efek Jakarta. Simposium Nasional Akuntansi XI.

Jensen, M. C., \&Meckling, W. H. (1976). Theory of the Firm: Managerial Behavior, Agency Costs and Ownership Structure. Journal of Financial Economics, 3(4), 305-360.

La Porta, R., Lopez-De-Silanes, F., and Shleifer, A. (1999). Corporate Ownership Around the World. The Journal of Finance, LIV(2), 471- 516. Literature, 25(1), 121-132.

Lev, B. (2003). Corporate Earnings: Facts and Fiction.Journal of Economic Perspectives, 17(2), $27-50$.

Pertiwi, T. K., \& Pratama, F. M. I. (2012). Pengaruh Kinerja Keuangan Good Corporate Governance Terhadap Nilai Perusahaan Food and Beverage. Jurnal Manajemen dan Kewirausahaan, 14(2), 118-127.

Purba, J. H. V. (2004). Pengaruh Proporsi Saham Publik terhadap Kinerja Perusahaan. Jurnal Ilmiah Ranggagading, 4(2), 109-116.

Rahmani, N. (2008). Analisis Efisiensi pada BUMN Privatisasi di Indonesia dengan Pendekatan Fungsi Produksi Cobb-Douglas(Master's thesis).

Rejeki, Sri. 2007. "Analisis Pengaruh Struktur Kepemilikan, Ukuran Perusahaan dan Rasio Perputaran Persediaan Terhadap Pemilihan Metode Persediaan pada Perusahaan Manufaktur Go Public di BEJ”. Skripsi Tidak Dipublikasikan, Fakultas Ekonomi, Universitas Semarang.

Sofyaningsih, S., \& Hardiningsih, P. (2011). Struktur kepemilikan, kebijakan dividen, kebijakan utang dan nilai perusahaan. Dinamika keuangan dan perbankan, 3(1).

Sujoko, dan Ugy Soebiantoro. 2007. Pengaruh Struktur Kepemilikan Saham, Leverage, Faktor intern dan Faktor Ekstern terhadap Nilai Perusahaan. Dalam Jurnal Manajemen dan Kewirausahaan, 9 (1): h. 41-48.

Wahyudi, U., \& Pawestri, H. P. (2006). Implikasi struktur kepemilikan terhadap nilai perusahaan: dengan keputusan keuangan sebagai variabel intervening. Simposium Nasional Akuntansi, 9, 1-25.

Wiagustini, N. L. P., \& Pertamawati, N. P. (2015). Pengaruh risiko bisnis dan ukuran perusahaan terhadap struktur modal dan nilai perusahaan pada perusahaan farmasi di bursa efek Indonesia. Jurnal Manajemen, 9(2), 1-1.

Networked: The Influence of Social Networking Sites on Political Attitudes and Behavior. Social Science Computer Review, 28(1), 75-92.

Jackowicz, Krzysztof \& Kozłowski, Łukasz \& Mielcarz, Paweł, 2014. "Political connections and operational performance of non-financial firms: New evidence from Poland," Emerging Markets Review, Elsevier, vol. 20(C), pages 109-135

Wati, L. N., Rachmat Sudarsono, S. E., Si, M., \& Erie Febrian, S. E. (2016). Corporate Governance On Conglomerates Pollitically Connected. International Journal of Business, Economics and Law, 10(1), 23-31.

Wati, L.N., Rachmat Sudarsono, S.E., Si, M. and Erie Febrian, S.E. 2016a. Corporate governance on conglomerates politically connected. International Journal of Business, Economics and Law, 10(1), pp.23-31.

Wati, L. N. 2017. Board of commissioner's effectiveness on politically connected conglomerates: Evidence from Indonesia. Pertanika Journal Social Sciences \& Humanities, 25(S), pp. 255270. 